\title{
A Comparative Analysis of Strategic Planning Based on a Systems Engineering Approach
}

http://doi.org/10.21272/bel.4(2).86-95.2020

Herlandí de Souza Andrade, ORCID: https://orcid.org/0000-0003-3293-3991

Professor, Engineering School of Lorena, University of São Paulo, São Paulo, Brazil

Geilson Loureiro, ORCID: https://orcid.org/0000-0002-9572-177X

Technologist, National Institute for Space Research, São Paulo, Brazil

\begin{abstract}
Strategic planning is an organizational process, the purpose of which is to conceive, formulate and manage the strategies implementation in the enterprise. The implementation of strategic planning involves the implementation of a set of actions aimed at taking the organization from a known position to a more desirable position, creating sustainable competitive advantages. This study deals with substantiating the role and importance of organizational strategic planning in the development of the organization using a systems approach. Systems engineering consists of a multidisciplinary and collaborative engineering approach, the purpose of which is to derive, develop and verify the effectiveness of decisions or the functioning of the system throughout its life cycle to satisfy the needs, expectations and desires of stakeholders. The purpose of this article is critically to analyze the Andrade method by comparing the processes and tools used in this method with those obtained as a result of traditional strategic planning. The methods were compared by developing a case study conducted in a science, technology and innovation institution operating in Brazil and annually conducting strategic planning cycles, using traditional methodologies for managing and analyzing the effectiveness of the organization and defining strategies for its development. The paper using the engineering system, carries out the comparison of the applied phases and tools with the offers in the model. The obtained results prove disadvantages of the traditional strategic planning process in comparison with the model proposed by Andrade. The application of the proposed model would allow to obtain indicators, different from the results of traditional strategic planning, in terms of forming another set of strategies and tools to manage the organization's development. The paper concludes that the model proposed by Andrade is more complex than the traditional one. It indicates the expediency of organizations using other tools to analyze and formulate company development strategies in the context of strengthening their competitive advantages and achieving strategic goals.
\end{abstract}

Keywords: Strategy, Strategic Planning, Strategic Planning Model, Strategic Management, Systems Engineering.

JEL Classification: L1, O21.

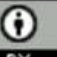

This work is licensed under a Creative Commons Attribution 4.0 International License

Cite as: Andrade, H. S., Loureiro, G. (2020). A Comparative Analysis of Strategic Planning Based on a Systems Engineering Approach. Business Ethics and Leadership, 4(2), 86-95. http://doi.org/10.21272/bel.4(2).86-95.2020.

(C) The Authors, 2020. This article is published with open access at Sumy State University.

\section{Introduction}

This paper addresses the development of organizational Strategic Planning through a Systems Engineering approach. Strategic Planning is an organizational process whose objective is to conceive, formulate and manage the implementation of strategies, that is, a set of actions aimed at taking the organization from a known position to another desired position, creating sustainable competitive advantages. Systems Engineering consists of a multidisciplinary and collaborative engineering approach whose objective is to derive, develop and verify a solution or a system throughout its life cycle, with the aim of satisfying the needs, expectations and desires of the stakeholders. Strategic Planning is applied for the development of organizations and Systems Engineering is applied for the development of complex products.

Andrade (2008) developed a model for Organizational Strategic Planning based on Systems Engineering considering that an organization is a complex system and, as such, can be developed through systems 
engineering, aiming to create strategies that are balanced to meet the diverse needs an organization's stakeholders. This model proposed by Andrade (2008) makes use of all the traditional tools of strategic planning, mixing them with the tools used in systems engineering, for example, tools for the deployment of objectives and targets, risk analysis and mapping of Lawsuit.

According to Andrade (2008) and Andrade and Loureiro (2018A, 2018C, 2017A), the strategic planning model based on Systems Engineering consists of several important tools to design, formulate and analyze strategies, combining each of the approaches (traditional strategic planning and systems engineering) has the best to offer. Thus, the most appropriate tools for each approach can be used, in each situation, to achieve the desired goals, leading to the development of the organization. Thus, the objective of this work is to present a critical analysis of the method proposed by Andrade (2008), by comparing the processes and tools incorporated into this method with the one obtained through the realization of traditional strategic planning. The comparison of the methods was carried out through the development of a case study carried out in a Scientific, Technological and Innovation Institution, active in the space area, in Brazil. The institution conducts strategic planning cycles annually, using traditional methodologies to guide its analysis and strategy definition activities. Thus, a comparison of the phases and tools applied was carried out with the proposals in the model based on systems engineering.

This work is organized in 4 chapters. The second chapter presents a literature review on the proposal for a Systems Engineering approach to Organizational Strategic Planning, considering the model proposed by Andrade (2008). The third chapter presents a comparative analysis of the traditional method of Strategic Planning applied by a science and technology organization in comparison with the method based on systems engineering approach, and finally, the fourth chapter presents the final considerations for the present work.

\section{A Systems Engineering Approach to Organizational Strategic Planning}

According Meresa (2019), strategic management can be defined as the art and science of formulating, implementing and evaluating cross-functional decisions that enable an organization to achieve its objective. Strategic Management is the on-going process of formulating, implementing and controlling broad plans guide the organizational in achieving the strategic goods given its internal and external environment. To enable strategic management, organizations make use of Strategic Planning, which aims to analyze the organization and its environment to create strategies that lead to more efficient and effective results, including, according to Lin et. al (2020), the improvement of existing conditions, resources and capacities to create competitive advantage. To Singh and Singh (2018), in general, the strategic planning process involves two main activities: formulation of strategies and choosing the best strategy from among multiple strategies to achieve the organizational objectives. Uzarski and Broome (2019), Broome, Bowersox, and Relf (2017), and Tapinos, Dyson and Meadows (2005) describes that the objective of strategic planning can be defined as a set of processes carried out to develop a series of strategies to help an organization achieve its goals and objectives over a period of up to five years.

According to Silva and Gonçalves (2011), strategic planning is used both in the private and public sectors, as an instrument for reducing uncertainties and guiding the organization's future steps, in order to obtain superior results. Currently, there are several models to follow for the development of strategic organizational planning, among them, the model proposed by Chiavenato and Sapiro (2003). This author describes that Strategic Planning is directed to medium- and long-term objectives that impact or affect the organization. However, if strategic planning is applied in isolation, it is not enough, as strategic planning does not act with operational and immediate actions. It is necessary to integrate the strategic plan with the organization's tactical and operational plans, articulating them. Strategic planning tools should allow the maximization of results and the minimization of deficiencies, using the principles of greater efficiency and effectiveness. In other words, "strategy points the way and Strategic Planning indicates how to walk it". The general model of the Strategic Planning process proposed by the author is composed of five main parts: "strategic design, strategic knowledge management, strategic formulation, strategic implementation and strategic evaluation and reevaluation", as shown in Figure 1. 
PART 1

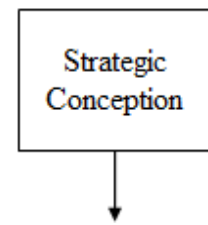

-Strategic Intent
PART 2

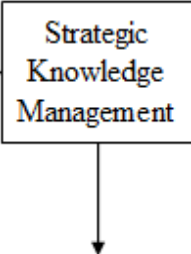

-External Diagnosis

-Internal Diagnosis

-Scenario Building
PART 3

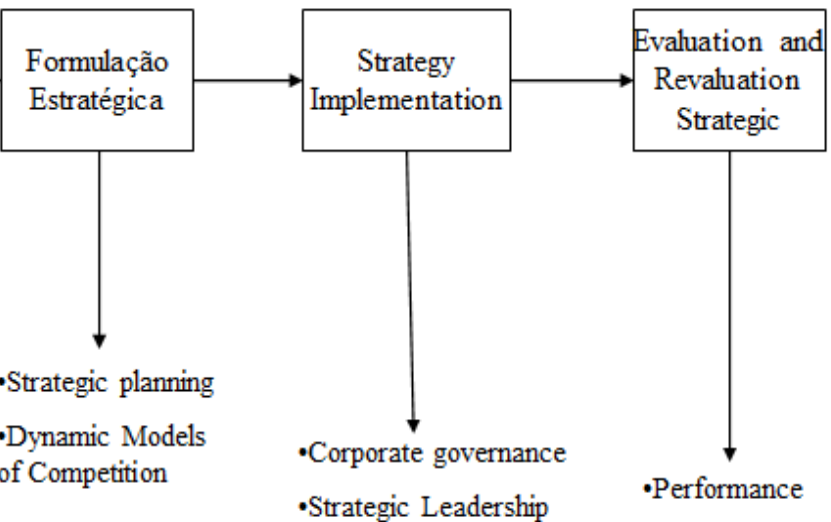

-Performance Audit

Figure 1. Strategic planning process - Chiavenato \& Sapiro approach

Source: Chiavenato and Sapiro, 2003

In the same way as strategic planning, in systems engineering, there are also several models available. Among them is the model by Loureiro (1999). The author presents the total view framework, which can be translated as "total view structure", a structured analysis method to derive the requirements and attributes of the product, process and organization. The method basically consists of the simultaneous analysis of the product, its life cycle processes and the organizations that perform them. The analysis process consists of the sub-processes: "requirements analysis, functional analysis and physical analysis", shown in the Figure 2.

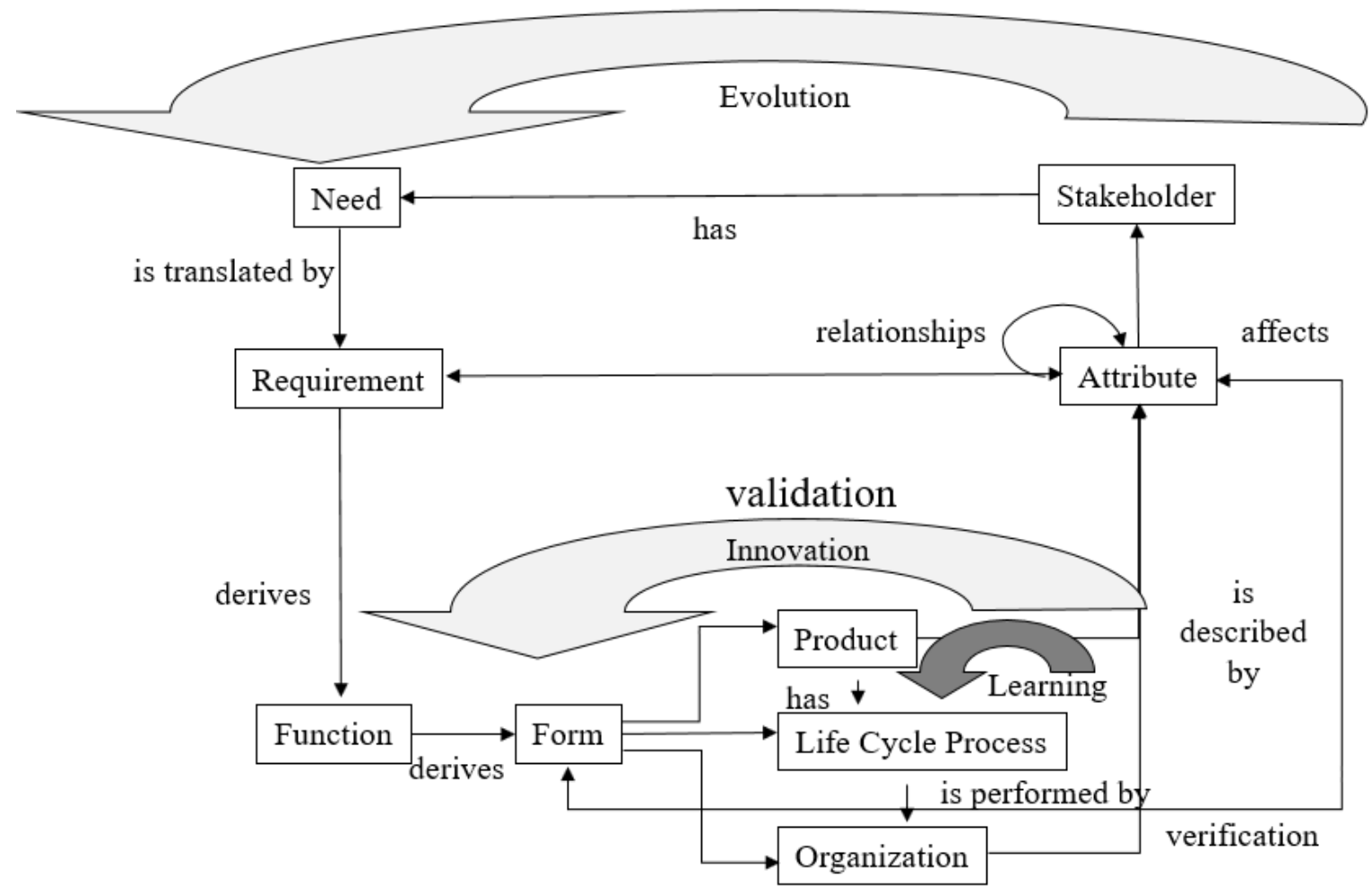

Figure 2. Systems engineering process: Structure of the total view - Loureiro approach

Source: Loureiro, 1999

According to Boscoianu, Prelipcean and Lupan (2018), Systems engineering signifies the process of defining and transforming the requirements within a system, by means of involving some multi-disciplinary issues (economic, political and social). To Price et. al (2013), systems engineering is a disciplined process for establishing needs, capabilities and requirements. To Wolff et. al (2017), systems engineering offers a rigorous methodology for recording, mapping and tracking system requirements at various hierarchical levels. 
Loureiro's model is also inspired by several other models, including the $\mathrm{V}$ model, by Forsberg and Mooz (1992), which reflects a top-down and bottom-up approach to systems development. The left side of the V represents the evolution of the user's requirements within the preliminary and detailed design, the right side represents the integration and verification of the system components through the subsystems and tests, as shown in Figure 3.

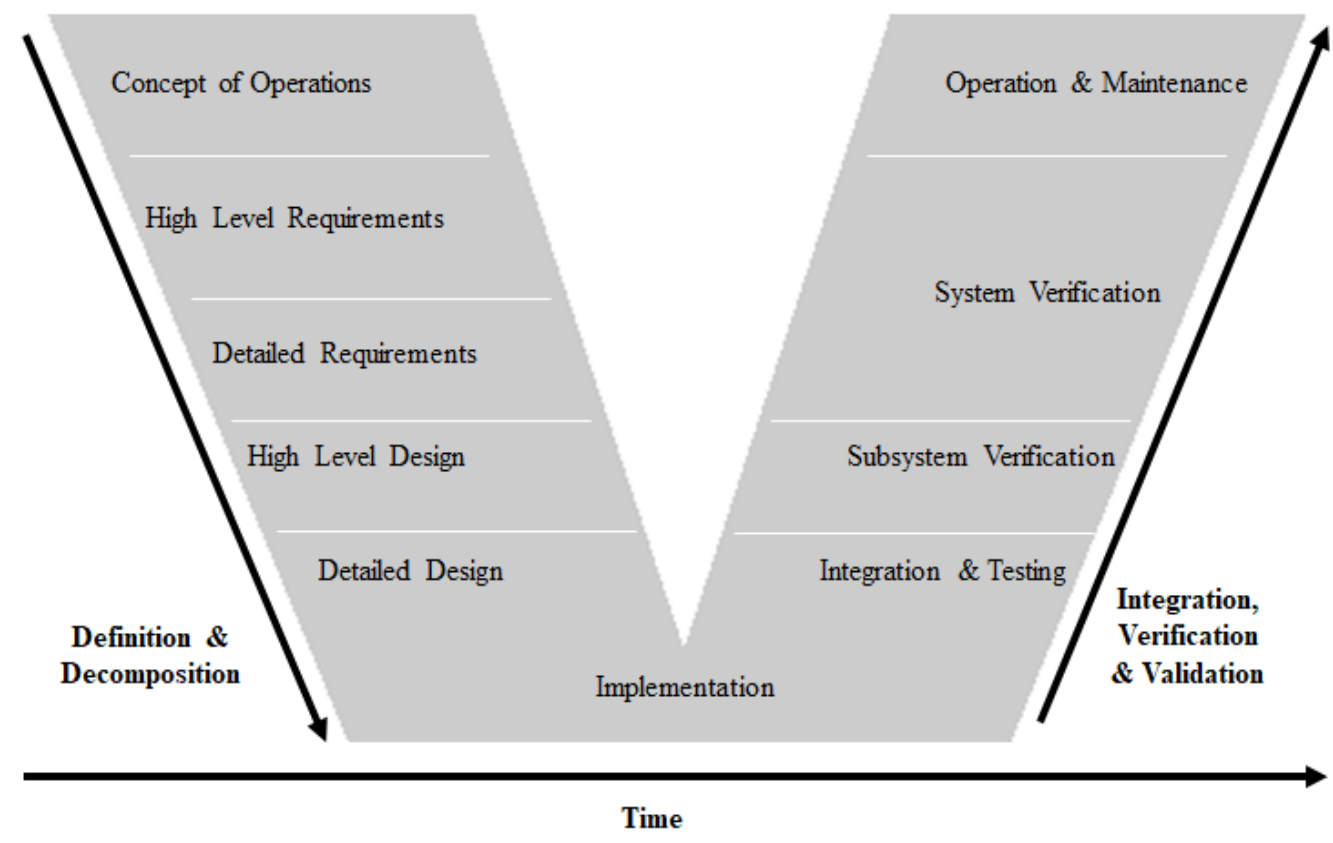

Figure 3. Model V by Forsberg and Mooz, 1992

Source: Elm et al., 2008

Thus, considering these three models, Andrade (2008) proposed a system engineering approach to strategic organizational planning, which reflects the consolidation of traditional Strategic Planning and Systems Engineering methods applied to the development of complex products. The choice of these two approaches to support the proposed method is since they are considered as integrated approaches, which even contain the principles of other authors' approaches. Figure 4 presents the conceptual model of the proposed approach.

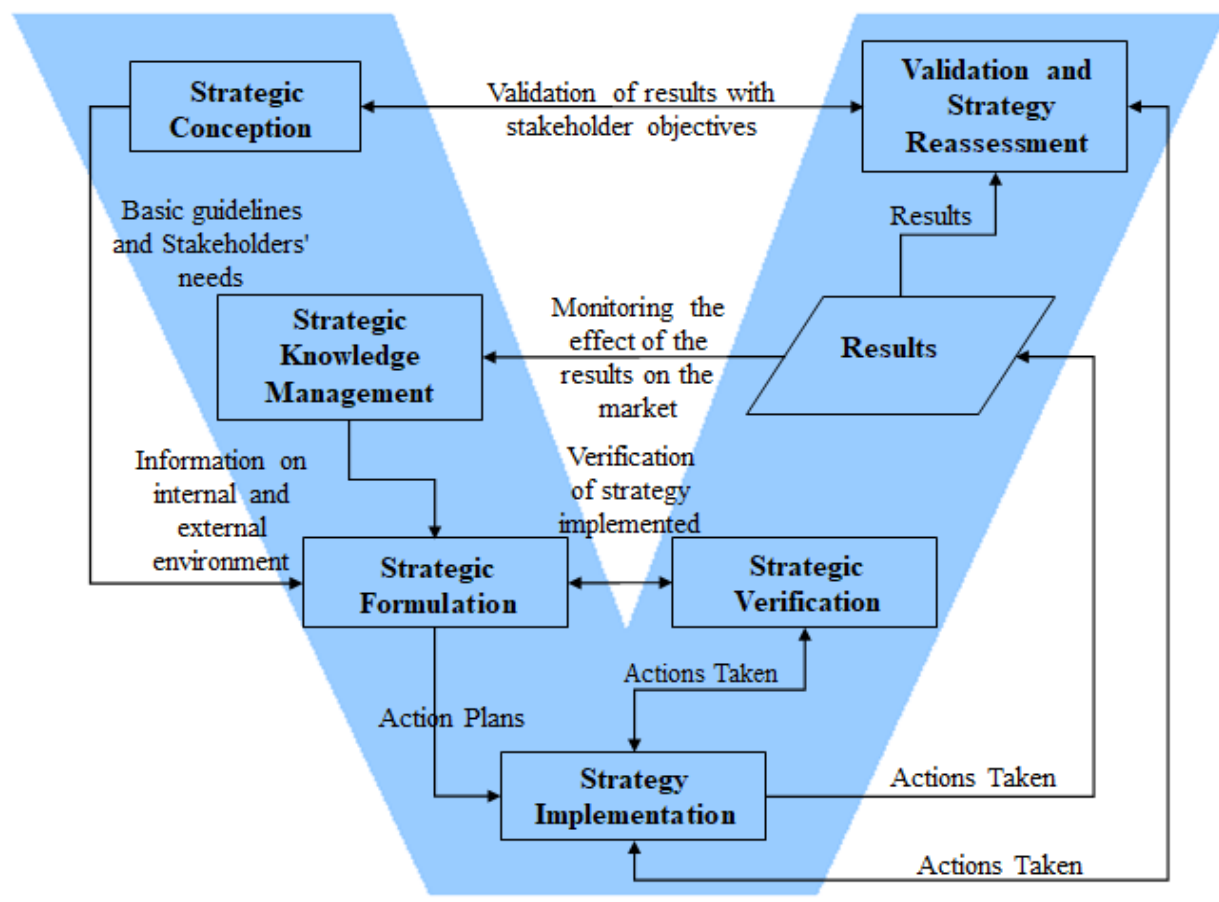

Figure 4. An approach for the organizational strategic planning based on systems engineering - Generic model Source: Andrade, 2008; Andrade and Loureiro, 2017; 2018B 
"The left side of the V has as main product the definition of the organization's strategy. On this side, the items of strategic design, strategic knowledge management and strategic formulation are allocated. At the base of the $\mathrm{V}$ is the implementation of the strategy, which represents the execution and integration of the actions defined in the strategic formulation. On the right side of the $\mathrm{V}$, there is the verification and validation of the strategy, which will assess whether the planned actions are being carried out and whether they are producing the expected result. Also, it is at this stage that improvement actions are taken, to make the defined actions feasible or adjust the strategy, in view of the market reality" (Andrade, 2008; Andrade and Loureiro, 2017A; Andrade and Loureiro, 2018B). The Figure 5 provides a view of the detailed model of the proposed approach for the preparation of the Strategic Planning presented in Figure 4. This is an iterative and structured process, which provides for the integration of product, process and organization.

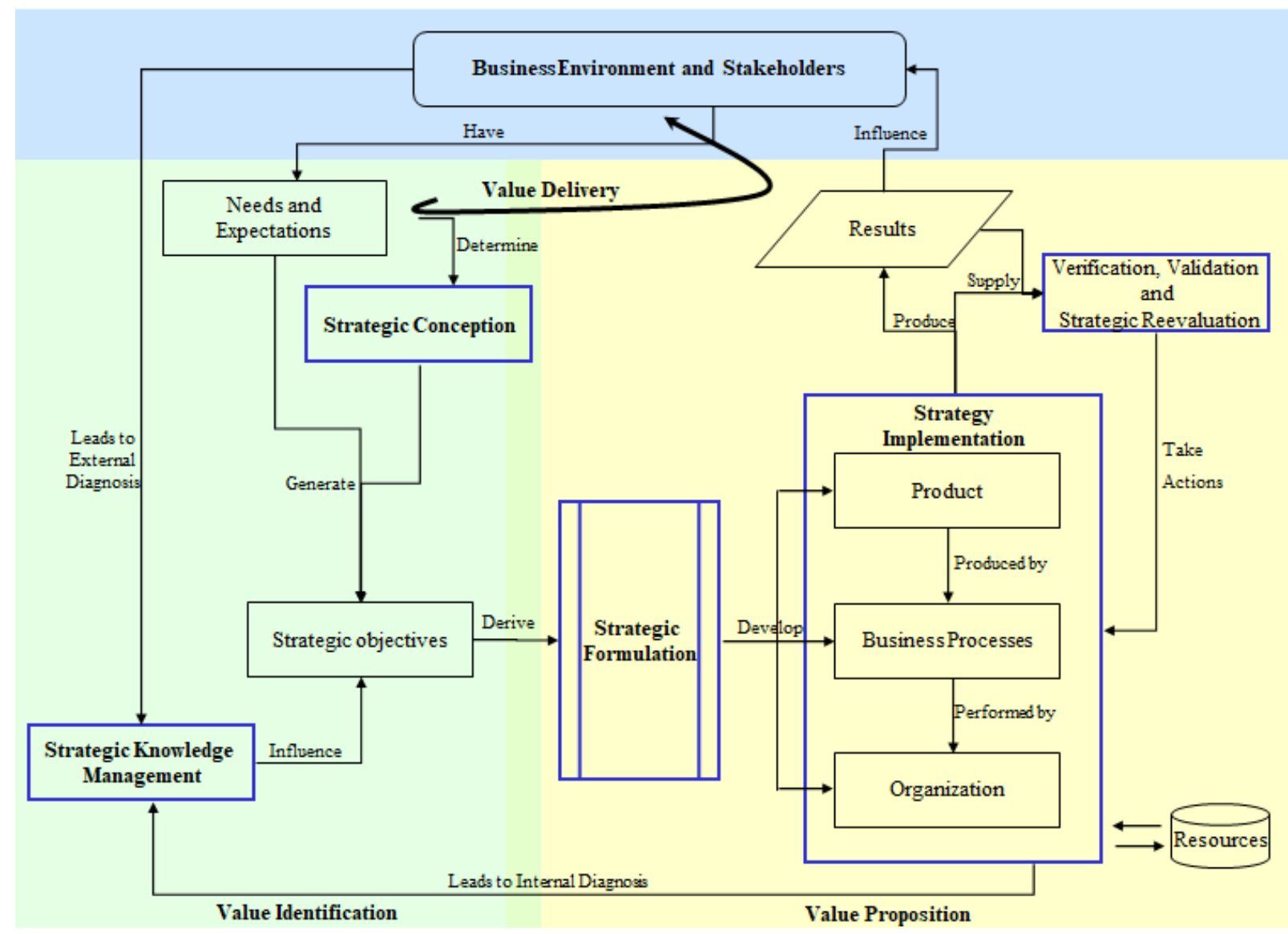

Figure 5. Systems engineering approach to strategic organizational planning

Source: Andrade, 2008; Andrade e Loureiro, 2017; 2018A; $2018 \mathrm{C}$

According to Andrade (2008) and Andrade and Loureiro (2018A; 2017A), the Figure 5 shows that stakeholders have needs and expectations that, in turn, determine strategic intent and, together with this, generate strategic objectives. Strategic objectives are also influenced by the management of strategic knowledge, which comes from external and internal diagnosis. Strategic objectives derive from strategic formulation, which develops product, business processes and organization. Each product is made or produced by an associated business process that, in turn, is performed by an organization.

The implementation of the strategy consists of applying the strategies previously defined in the products, business processes and organization. Product, processes and organization, through the implementation of the strategy, produce results. These results, combined with the actions taken to implement the strategy, feed the strategic assessment and reassessment, which verify whether the planned actions were carried out satisfactorily and whether the results are consistent with the needs and expectations of the stakeholders. If so, they reinforce the application of the strategy and, if not, reevaluate the strategy and take actions to correct or improve it. Also, you can see in the Figure 5 the issue of generating value for stakeholders. According to Deglane et al. (2018B; 2017A), stakeholder analysis is recognized as a trend that allows aligning the objectives of the organization, or the project developed by it, with the demands of the stakeholders. For this, it is important, initially, to identify the stakeholders of the project. Once stakeholders have been identified, according to Kerzner (2002) 
and Keeling (2002), it becomes necessary to identify the requirements of the main stakeholders, to plan actions to adapt to the different needs, concerns and expectations of stakeholders.

Adapted from the affirmations of Prazeres (1996) and Chiavenato and Sapiro (2003), value is a characteristic added to a solution, determined by the needs and expectations of the stakeholders or by the functions that he expects the solution to have. It corresponds to the sum of the benefits expected to receive from a solution. On the left side of the table, from the stage of needs and expectations to strategic objectives, it is about the identification of value; and on the right side of the table, from strategic formulation to strategic assessment and reevaluation, this is the value proposition. The delivery of value is related to the results delivered versus the needs and expectations pointed out initially by the stakeholders. According to Murman et al. (2002), the value is delivered when a process acts on the system, so that the needs of the stakeholders are met. To implement the method, it is necessary to use appropriate tools for each phase of the Organizational Strategic Planning. Table 1 presents the details of each of the steps of the proposed method.

Table 1. Detailing of the systems engineering approach to strategic organizational planning

\begin{tabular}{|c|c|}
\hline \multicolumn{2}{|c|}{ Strategic Planning - Systems Engineering Approach } \\
\hline \multirow{3}{*}{ Identification of Stakeholders' Needs and Expectations } & Stakeholders identification \\
\cline { 2 - 2 } Strategic Conception & Identification of Stakeholders' Needs \\
\hline \multirow{3}{*}{ Strategic Knowledge Management } & Determine the Organization's Business \\
\cline { 2 - 2 } & Conception of the Organization's Vision \\
\cline { 2 - 2 } & Identify the Central Ideology of the Organization \\
\cline { 2 - 2 } & Identify business processes \\
\cline { 2 - 2 } Establishment of Strategic Objectives & Perform External Diagnosis \\
\cline { 2 - 2 } & Perform Internal Diagnosis \\
\cline { 2 - 2 } & Conild and Analyze Scenarios \\
\cline { 2 - 2 } & Perform Risk Analysis \\
\cline { 2 - 2 } Strategic Formulation & Consolidation of Strategic knowledge Objectives \\
\cline { 2 - 2 } & Critical Success Factors \\
\cline { 2 - 2 } & Unfold the objectives and goals \\
\hline Strategy Implementation & Strategic action planning \\
\hline \multirow{2}{*}{ Strategic Verification and Validation } & Skills Development Plan \\
\hline Strategic Revaluation & Monitoring the Action Plan \\
\cline { 2 - 2 } & Strategic Evaluation and Reassessment Plan \\
\cline { 2 - 2 }
\end{tabular}

Source: Andrade, 2008

Uzarski and Broome (2019) describes that the implementation of a comprehensive strategic plan is not an easy task. It requires organization, resource allocation and continual assessment of the plan's progress. According to Chiavenato and Sapiro (2003), "it is worth remembering that it often comes up against people when trying to formulate, implement or evaluate a strategy. People can be the competitive advantage, but they can also be the obstacle to their effective realization. This is because, when it comes to a strategy, its evaluation must cover from the stage of strategic intention, management of external and internal strategic knowledge, strategic formulation until the implementation of the strategy in terms of performance and execution as it is being placed in practice; but the final stage refers, almost always, to the results that it manages to achieve. All of this is done through people. A strategy without people is not formulated or implemented. They are essential stakeholders in this task".

\section{Comparative Analysis of the Proposed Model for Strategic Planning Using Systems Engineering with a Traditional Model}

This comparative analysis was carried out through a case study in an Institution of Science, Technology and Innovation, with outstanding performance in the Brazilian space sector. Thus, the strategic planning carried out was taken as a basis to allow its comparison with the structure and analyzes carried out with the proposed model. Still, to make such a comparison, it was necessary to hold meetings and interviews with employees of the institution, to complement the information regarding the process of preparing such a strategic planning cycle. The institution adopted the Institutional Foresight methodology for the development of its strategic planning cycle. It is an approach developed based on planning concepts in science, technology and innovation, in the public and private sectors, and scientific and technological prospecting practices. In general terms, According to INPE (2006B) the Institutional Foresight is a combination of prospecting, planning and formation 
of relationship networks, which converges to the establishment of commitments, to change and, consequently, to the sharing of responsibilities, to formulate and perform actions. According to INPE $(2019 ; 2007 ; 2006 \mathrm{~A})$, the Strategic Planning and Evaluation Coordination (CPA) was responsible for conducting strategic planning activities. To guide the conceptualization of the document, the group used the following premises:

- The strategic objectives should observe the alignment with the national programs, as well as the availability of human resources, physical structure and financial resources of the institution.

- Research and Development areas should include, in their contributions, a reflection on the future.

- All proposals should be under the aegis of observing the state of the art, the generation of frontier knowledge and applied research, as a basis for the development of innovative products and services for the benefit of society.

- The Master Plan should reflect and draw attention to the needs and needs of the Institute in the area of management.

According to INPE (2019), the works were structured in five stages, namely:

1. Evaluation of the 2011-2015 Master Plan and preparation of a proposal for the 2016-2019 Master Plan.

2. Forwarding the form to the finalistic and management areas for the development of its strategic objectives, with characterization (contextualization / diagnosis) and quantifiable goals.

3. Analysis and consolidation of the proposals submitted, through interaction with the areas.

4. Preparation of the first version of the final document of the Master Plan.

5. Validation of the Master Plan by the Direction and by the areas.

An extensive set of activities was carried out within the scope of the institution's strategic planning process, with emphasis on the development of thematic studies, mapping the existing competencies in the institution, identification of alternative future scenarios for science, technology and innovation in the space and environment areas in Brazil, panels with specialists, lectures and seminars. The result of this exercise served as a basis for defining trajectories, for the institute and for its positioning in relation to the alternatives presented. Table 2 presents a comparison of the items contained in the Strategic Planning process based on systems engineering, proposed by Andrade (2008) with that carried out in a traditional way by the institution.

Table 2. Comparison between the traditional model analyzed and the model based on a systems engineering approach

\begin{tabular}{|c|c|c|}
\hline \multicolumn{2}{|c|}{$\begin{array}{c}\text { Systems Engineering Approach to Strategic Planning } \\
\text { According to Andrade (2008) }\end{array}$} & \multirow{2}{*}{$\begin{array}{c}\text { Traditional Strategic Planning } \\
\text { applied by the organization }\end{array}$} \\
\hline Identification of Stakeholders' & Stakeholders identification & \\
\hline Needs and Expectations & Identification of Stakeholders' Needs & Partial \\
\hline \multirow{4}{*}{ Strategic Conception } & Determine the Organization's Business & Yes \\
\hline & Conception of the Organization's Vision & Yes \\
\hline & Identify the Central Ideology of the Organization & Partial \\
\hline & Identify business processes & No \\
\hline \multirow{5}{*}{$\begin{array}{l}\text { Strategic Knowledge } \\
\text { Management }\end{array}$} & Perform External Diagnosis & Yes \\
\hline & Perform Internal Diagnosis & Yes \\
\hline & Build and Analyze Scenarios & Yes \\
\hline & Perform Risk Analysis & No \\
\hline & Consolidation of strategic knowledge & No \\
\hline \multirow{3}{*}{$\begin{array}{l}\text { Establishment of Strategic } \\
\text { Objectives }\end{array}$} & Consolidation of Strategic Objectives & Partial \\
\hline & Critical Success Factors & No \\
\hline & Unfold the objectives and goals & Partial \\
\hline \multirow{2}{*}{ Strategic Formulation } & Strategic action planning & Partial \\
\hline & Skills Development Plan & No \\
\hline Strategy Implementation & Implementation of Strategic Actions & Yes \\
\hline \multirow{2}{*}{$\begin{array}{l}\text { Strategic Verification and } \\
\text { Validation }\end{array}$} & Monitoring the Action Plan & Partial \\
\hline & Result Evaluation & Partial \\
\hline Strategic Revaluation & Strategic Evaluation and Reassessment Plan & No \\
\hline
\end{tabular}

Source: Compiled by authors 
Comparing the method used by the institution, the following points can be observed:

- The business, mission, vision and values were designed according to the needs of the stakeholders, however, not all the institution's stakeholders were identified. The institution's mission, vision and values were then consolidated and after that, based on the studies previously carried out, strategic objectives and actions were established. In the process of establishing strategic objectives, current and future challenges for the space and terrestrial environment areas at national and international levels were considered, as well as the conditions capable of contributing to the institution's competitiveness and sustainability, long term.

- The existing internal policies in the Strategic Planning have not been consolidated.

- The processes have not been mapped. There was a mapping to identify the main competences of the institute. If the processes had been mapped, they could establish objectives directed to the processes, thus facilitating the attendance to them, during their deployment in the operational plans.

- Internal and external diagnosis and scenario construction were carried out; however, a previous risk analysis was not carried out. When we identify risks in advance, we can indicate actions to counter the effects of the risk.

- A specific tool was not noticed to derive the needs of stakeholders in specific strategic objectives. The use of an appropriate tool is important, as it translates needs that are usually placed in an unstructured way in a specific objective, in addition to providing a structure for their measurement.

- The identification of critical success factors was also not noticed. It is important to identify these factors, as they show us the key activities of the organization. To those activities that we must maximize the performance.

- For each objective, strategic actions were assigned, but the objectives were not broken down into clearly defined goals. When the objectives are broken down into goals, we can see where we really want to go and, thus, it is easier to establish the strategic actions to achieve those goals.

- It was not possible to identify a training plan for people to successfully implement the defined strategic actions and their respective objectives. A mapping of current competences was carried out.

- The monitoring of the plan's actions, as well as the evaluation of the results achieved, are carried out partially, not including the analysis indicated in the proposal. The strategic reassessment is not carried out after obtaining the initial results.

Evaluating the result presented in Table 2, it can be observed that the traditional Strategic Planning process has gaps in relation to the model proposed by Andrade (2008). This may indicate that if the proposed model were adopted, the result could be different from that obtained with traditional strategic planning, in terms of generating other different strategies or strategies, considering that other analyzes would be carried out.

\section{Final Considerations}

This paper presented an analysis of the development of strategic planning using a traditional approach, comparing it with a strategic planning model conceived from a systems engineering approach. With this comparison, it was possible to observe the gaps related to the analysis and formulation of strategies, as well as in their validation, evaluation and reassessment, from the traditional model to the proposed model. Considering Table 2, it can be considered that the traditional model of strategic planning used by the institution completely executed only 6 of the 20 items contained in the model proposed by Andrade (2008), representing 30\%, partially executed 8 items partially, representing $40 \%$ and the traditional model did not fully or partially include 6 of the proposed items, representing $30 \%$.

Among the items partially contemplated are the following: Stakeholders identification, Identification of Stakeholders' Needs, Identify the Central Ideology of the Organization, Consolidation of Strategic Objectives, Unfold the objectives and goals, Strategic action planning, Monitoring the Action Plan and Result Evaluation. The items not included are: Identify business processes, Perform Risk Analysis, Consolidation of strategic knowledge, Critical Success Factors, Skills Development Plan and Strategic Evaluation and Reassessment Plan. In this way, it can be considered that the model proposed by Andrade (2008) is more comprehensive than the traditional model used, thus allowing organizations to use other tools for analyzing and formulating strategies for the company to develop competitive advantages and achieve your goals. 


\section{References}

1. Andrade, H. S. (2008). Uma abordagem da engenharia de sistemas para o planejamento estratégico organizacional. 135f. Tese de Mestrado - Instituto Tecnológico de Aeronáutica, São José dos Campos. [A systems engineering approach to strategic organizational planning]. Available at: http://www.bdita.bibl.ita.br/tesesdigitais/lista_resumo.php?num_tese $=000551300$ (accessed May 26, 2020).

2. Andrade, H. S., Loureiro, G. (2018A). An analysis on the application of the Strategic Planning model based on Systems Engineering. International journal of advanced engineering research and science, 5, 1-4. https://doi.org/10.22161/ijaers.5.7.1.

3. Andrade, H. S., Loureiro, G. (2017). Planejamento Estratégico: uma abordagem de Engenharia de Sistemas. [Strategic Planning: a Systems Engineering approach]. Balti: Novas Edições Acadêmicas, 1, 111. Available at: (accessed May 26, 2020). ISBN: 978-620-2-40226-2.

4. Andrade, H. S., Loureiro, G. (2018C). Proposta de um modelo de planejamento estratégico baseado em engenharia de sistemas. [Proposal for a strategic planning model based on systems engineering]. ESPACIOS (CARACAS), 39(13), $10 . \quad$ Available at: http://www.revistaespacios.com/a18v39n13/18391310.html (accessed May 26, 2020).

5. Andrade, H. S., Loureiro, G. (2018B). Strategic Planning: a model based on Systems Engineering. International journal of advanced engineering research and science, 5, 67-71. https://doi.org/10.22161/ijaers.5.3.10.

6. Chiavenato, I., Sapiro, A. (2003). Planejamento estratégico: fundamentos e aplicações, da intenção aos resultados. Rio de Janeiro: Elsevier. [Strategic planning: fundamentals and applications, from intention to results]. ISBN: 978853522666.

7. Deglane, K. C. B., Loures, L. E. V. C., Silva, R. G. A., Andrade, H. S. (2017A). Proposta de um método para análise de stakeholders em projetos aeroespaciais. [Proposal for a method for stakeholder analysis in aerospace projects]. ESPACIOS (CARACAS), 38(24), $10 . \quad$ Available at: https://www.revistaespacios.com/a17v38n24/17382410.html (accessed May 26, 2020).

8. Deglane, K. C. B., Loures, L. E. V. C., Silva, R. G. A., Andrade, H. S., Silva, M. B. (2017B). Stakeholders analysis in complex projects. International Journal of Humanities and Social Science Invention, 6, 73-81. Available at: http://www.ijhssi.org/papers/v6(9)/Version-4/L0609047381.pdf (accessed May 26, 2020).

9. Elm, W. C.; Gualtieri, J. W.; Mckenna, B. P.; Tittle, J. S.; Peffer, J. E.; Szymczak, S. S.; Grossman, J. B. (2008). Integrating Cognitive Systems Engineering Throughout the Systems Engineering Process. Journal of Cognitive Engineering and Decision Make, 2(3), 249-273. Available at: https://journals.sagepub.com/doi/pdf/10.1518/155534308X377108 (accessed May 26, 2020).

10.Forsberg, K., Mooz, H. (1992). The relationship of systems engineering to the project cycle. Engineering Management Journal, 4(3), 36-43. https://doi.org/10.1080/10429247.1992.11414684.

11.Instituto Nacional De Pesquisas Espaciais - INPE (2006A). Planejamento estratégico do INPE: metodologia e conceitos: apresentação ao grupo gestor. São José dos Campos, 2006A. [INPE's strategic planning: methodology and concepts: presentation to the management group]. Available at: http://www.inpe.br/gestao/planejamento/documentos/arquivos/PE_Inpe_VisaoGeral.pdf (accessed May $24,2020)$.

12.Instituto Nacional De Pesquisas Espaciais - INPE. (2019). Plano Diretor 2016-2019. [2016-2019 Master Plan]. (accessed May 24, 2020). Available at: http://www.inpe.br/gestao/planejamento/planodiretor/arquivos/Plano_Diretor_2016-2019.pdf.

13.Instituto Nacional De Pesquisas Espaciais - INPE (2007). Plano Diretor do INPE 2007-2011: planejamento estratégico do INPE. São José dos Campos. [INPE Master Plan 2007-2011: INPE strategic planning]. Available at: http://www.inpe.br/gestao/planejamento/plano-diretor/arquivos/Plano_Diretor_20072011.pdf (accessed May 24, 2020).

14.Instituto Nacional De Pesquisas Espaciais - INPE (2006B). O Foresight institucional como metodologia para o planejamento. São José dos Campos. Nota Técnica Metodológica. [Institutional Foresight as a methodology for planning]. Available at: www.inpe.br/gestao/planejamento/documentos/arquivos/Apresentacao2406.pd (accessed May 24, 2020).

15.Keeling, R. (2002). Gestão de Projetos: uma abordagem global. São Paulo: Saraiva. [Project Management: a global approach]. ISBN: 9788502227101.

16.Kerzner, H. (2002) Gestão de Projetos: as melhores práticas. Porto Alegre: Bookman. [Project Management: best practices]. ISBN: 9788582605295.

17.Lin, H. E., Hsu, I. C., Hsu, A. W., Chung, H. M. (2020). Creating competitive advantages: Interactions between ambidextrous diversification strategy and contextual factors from a dynamic capability 
perspective. Technological Forecasting and Social Change, 154, 1-11. https://doi.org/10.1016/j.techfore.2020.119952.

18.Loureiro, G. (1999). A system engineering and concurrent engineering framework for the integrated development of complex products. England: Loughborough University, 606 p. Available at: https://repository.lboro.ac.uk/articles/A_systems_engineering_and_concurrent_engineering_framework_f or_the_integrated_development_of_complex_products/9544763 (accessed May 24, 2020).

19.Meresa, M. (2019). The Effect of Strategic Management Practices on the institutional Performance; the case of Dedebit credit and saving institution in Eastern Tigray. SocioEconomic Challenges, 3(3), 80-97. http://doi.org/10.21272/sec.3(3).80-97.2019.

20.Murman, E.; Allen, T.; Bozdogan, K.; Cutcher-Gershenfeld, J.; Mcmanus, H.; Nightingale, D.; Windnall, S. (2002). Lean enterprise value: Insights from MIT'S lean aerospace initiative. New York: Palgrave. https://doi.org/10.1057/9781403907509.

21.Prazeres, P. M. (1996). Dicionário de termos da qualidade. São Paulo: Atlas. [Dictionary of quality terms]. ISBN: 9788522413850.

22.Singh, S. P.; Singh, P. (2018). An Integrated AFS-Based SWOT Analysis Approach for Evaluation of Strategies Under MCDM Environment. Journal of Operations and Strategic Planning, 1(2), 129-147. https://doi.org/10.1177/2516600X18801689.

23.Uzarski, D.; Broome, M. E. (2019). A Leadership Framework for Implementation of an Organization's Strategic Plan. Journal of Professional Nursing, 35(1), 12-17. ISSN 8755-7223. https://doi.org/10.1016/j.profnurs.2018.09.007.

24.Broome, M., Bowersox, D., Relf, M. (2017). A new funding model for nursing education through business development initiatives. Journal of Professional Nursing, 34(2), 97-102. https://www.sciencedirect.com/science/article/pii/S8755722317302314.

25.Tapinos, E., Dyson, R., Meadows, M. (2005). The impact of the performance measurement in strategic planning. International Journal of Productivity and Performance Management, 54(5), 370-384. https://www.emerald.com/insight/content/doi/10.1108/17410400510604539/full/html.

26.Silva, F. A., Gonçalves, C. A. (2011). The process of formulating and implementing strategic planning in public sector institutions. Revista de Administração da UFSM, [S.l.], 4(3), 458-476. ISSN 1983-4659. doi: http://dx.doi.org/10.5902/198346593833.

27.Boscoianu, M., Prelipcean, G., Lupan, M. (2018). Innovation enterprise as a vehicle for sustainable development - A general framework for the design of typical strategies based on enterprise systems engineering, dynamic capabilities, and option thinking. Journal of Cleaner Production, 172, 3498-3507. ISSN 0959-6526. https://doi.org/10.1016/j.jclepro.2017.06.120.

28.Price, R. R., Singh, B. P., Mackinnon, R. J., Sevougian, S. D. (2013). The application of systems engineering principles to the prioritization of sustainable nuclear fuel cycle options. Energy Policy, 53, 205-217, ISSN 03014215. https://doi.org/10.1016/j.enpol.2012.10.051.

29.Wolff, D., Brown, R., Curson, P., Ellis, R., Galliara, T., Harris, M. (2017). Early Lessons from the Application of Systems Engineering at UKAEA. IEEE Transactions on Plasma Science, 46(5), 1725-1734. https://doi.org/10.1109/TPS.2018.2819726. 